М. М. ЗІНЧУК, д-р геол.-мінерал. наук, професор, академік АН РС (Я), голова Західноякутського наукового центру Академії наук Республіки Саха (Якутія), м. Мирний, nnzinchuk@rambler.ru, https://orcid.org/0000-0002-9682-3022
M. ZINCHUK, Dr. Sci. (Geol. \& Mineral.), Professor, Academician of the West-Yakutian Scientific Centre of the Sakha Republic (Yakutiia), Myrnyi, nnzinchuk@rambler.ru, https://orcid.org/0000-0002-9682-3022

\title{
ПРО ХАРАКТЕРИСТИКУ АЛМАЗІВ З ДАВНІХ ОСАДОВИХ ТОВЩ КРАЙОВИХ ЧАСТИН ПЛАТФОРМ
}

\section{О ХАРАКТЕРИСТИКЕ АЛМАЗОВ ИЗ ДРЕВНИХ ОСАДОЧНЫХ ТОЛЩ КРАЕВЫХ ЧАСТЕЙ ПЛАТФОРМ}

\author{
ABOUT CHARACTERISTICS OF DIAMONDS FROM ANCIENT SEDIMENTARY \\ THICK LAYERS OF MARGINAL PARTS OF PLATFORMS \\ (Матеріал друкуеться мовою оригіналу)
}

На підставі проведених комплексних досліджень підтверджено припущення щодо різних особливостей алмазів 3 кількох перспективних ділянок Тунгуської алмазоносної субпровінції, серед яких найперспективнішими є деякі території Байкітської та Південнотунгуської областей. Істотний вплив на формування тут давніх розсипів алмазів має докембрійська фаза кімберлітового магматизму в Присаянні та інших подібних структурах Сибірської платформи, звідки кристали зносилися в Іркутський амфітеатр. Обгрунтовано гіпотезу про приурочення областей поширення округлих алмазів до полів розвитку докембрійських теригенних формацій. Це дає змогу прогнозувати виявлення високопродуктивних тіл і в крайових частинах давніх платформ, що вже засвідчено на прикладі Східноєвропейської платформи Результати вивчення алмазів уможливлюють термальний вплив на кристали в умовах давніх вторинних колекторів магматичних утворень трапової формації, що спричинило перехід зелених плям пігментації в бурі. Судячи з наявності баласів у розсипах басейну р. Нижня Тунгуска, карбонадо в басейні верхньої течії р. Вілюй і баласів тунгуського типу в Середньомархінському алмазоносному районі (СМАР), типових округлих алмазів і тригонтриоктаедрів I різновиду, знесення таких алмазів могло сягнути зони зчленування Тунгуської синеклізи й Анабарської антеклізи (межиріччя Марха - Тюнг). За низкою типоморфних особливостей вивчені алмази близькі до кристалів розсипів Уралу й Середнього Тіману, але на відміну від них, характеризуються вищим (не менш як у 3-5 разів) умістом ламінарних кристалів ряду октаедр-ромбододекаедр, що свідчить про полігенезу їхніх корінних джерел (не менш як двох полів докембрійської фази й одного - мезозойської фази магматизму). Типоморфні особливості алмазів важливі для палеографічних реконструкцій поширення давніх продуктивних відкладів. Проведене мінералогічне районування території розсипної алмазоносності за типоморфними особливостями алмазів відкриває можливості локалізації перспективних площ і пошуку корінних джерел цього мінералу, що є набагато стійкішим в екзогенних умовах, порівнюючи з іншими мантійними утвореннями. Отримані типоморфні особливості алмазів описуваних осадових товщ можна також використати для відновлення екзогенної історії на шляху від їхніх джерел до місць сучасного розміщення в розсипах, що дуже важливо для визначення джерел знесення алмазоносного матеріалу.

Ключові слова: Сибірська платформа, докембрійські алмазоносні формації, районування територій, прогнозування та пошук родовищ.

Basing on carried out complex investigations' opinion about various features of diamonds from a number of perspective sites of Tunguska diamondiferous sub-province has been confirmed. Among the sites some territories of Baikitsk and South-Tunguska areas are most perspective. Sufficient influence on formation of ancient diamond placers here has been exerted by Pre-Cambrian phase of kimberlite magmatism in Prisayanie and other similar structures of the Siberian platform, from where crystals were carried to Irkutsk amphitheatre. An opinion has been passed about confinedness of rounded diamonds' areas of distribution to the fields of Pre-Cambrian terrigenous formations' development, which allows forecasting discovery of high-productive bodies in marginal parts of ancient platforms, as well, that has been confirmed on the example of East-European platform. Results of diamonds investigation allow assuming possibility of thermal impact on crystals in conditions of ancient secondary collectors of trappean formation magmatic initiations, which led to transition of green pigmentation spots into brown spots. The received typomorphic features of diamonds of the discussed sedimentary thick layers can be used for restoration of exogenous history on the path from their sources to the places of modern location in placers, which is very important for determination of source areas of diamondiferous material. Judging by the presence of balasses in placers of the Nizhnyaya Tunguska viver basin carbonado in the upper river basin of the Vilyuy river and Tunguska type balasses in the Sredne-Marchinski diamant rayon (SMDR) typical rounded diamonds and tri gontriotahedra of the ist species, the demolition of such diamonds could reach the yunction zone of the Tunguska syneclise and Anabar (Anabariskhe anche-Anechariche river Trung). According to a number of typomorphic features, the studied to a number of typomorphic features, the studied diamonds are close to the resip crystals of the Urals and Middle Timan, but their distrinction is characterized by a higher (not less than 3-5 times) content of laminar crystals of a number of octahedron-rhombododecahedron which testifies to the polygenesis of their root sources (no less than two fields of the Precambrian phrase and one for the Mesozoic phase of magmatism). Typomorphic features of diamonds are important for paleographic reconstructions of the spread of ancient prolific deposits. The mineralogical zoning of the peacer diamond area by typomorphic features of diamonds opens up the possibility of localizing promising areas and searching for the source of this mineral, which is much more stable under exogenous conditions compared to other mantle formations.

Keywords: Siberian platform, Pre-Cambrian diamondiferous formations, zoning of territories, forecasting and prospecting of deposits.

Открытие в 1954 году на территории Республики Саха (Якутия) первой алмазоносной кимберлитовой трубки Зарница привело впоследствии к концентрации основных прогнозно-

М. М. Зінчук, 2021, с. 13-19 поисковых работ на алмазы на этой территории, расположенной в центральной части Сибирской платформы (СП). Перспективы рудоносности остальных частей платформы остались до настоящего времени не реализованы, и в первую очередь это относится к краевым её частям [16, 19-26] 
В число таких слабо изученных территорий входит Тунгусская алмазоносная субпровинция (ТАСП), расположенная на юго-западе СП (бассейн р. Нижняя Тунгуска и Присаянье), где поисковые работы на алмазы на протяжении последних более 60 лет велись в очень незначительных объемах. В настоящей работе использованы результаты изучения алмазов, проведенные под руководством автора совместно с канд. геол.-минер. наук В. И. Коптилем. В ТАСП по типоморфным особенностям алмазов выделены [1-8] две области - Байкитская, включающая северную часть Енисейского кряжа и Байкитскую антеклизу, и Южно-Тунгусская. В Байкитской алмазоносной области (БАО), наряду с ранее установленными четвертичными проявлениями алмазов, в 80-х годах ХХ столетия зафиксированы индикаторные минералы кимберлитов (ИМК) и алмазы в средне-верхнекаменноугольных углисто-терригенных отложениях Тычанской и Тарыдакской (левобережье р. Подкаменная Тунгуска, в бассейне её левых притоков - Тарыдак, Бедошемо, Немба) алмазоносных площадей. Указанные отложения верхнего палеозоя сложно интрудированы телами долеритов, перекрыты триасовыми туфогенными образованиями и залегают на размытой поверхности терригенно-карбонатных пород среднего-верхнего кембрия или на сохранившейся на них коре выветривания (KВ). Базальные горизонты этих отложений, содержащие алмазы, представлены маломощными (до 1 м) линзовидно залегающими песчано-галечными образованиями (пролювиально-аллювиальные фации) или неотсортированными песчано-глинистыми образованиями с угловатыми обломками кремней, кварцитов и карбонатных пород, а также дресвяно-щебнистыми отложениями (делювиально-пролювиальные фации). Находящиеся в этих терригенных образованиях ИМК характеризуются высокой степенью сортировки и износа материала.

В Байкитской области детально изучены [11-13] алмазы из пространственно разобщённых участков каменноугольного коллектора Тычанской (десять участков), Шушукской (один участок) и Тарыдакской (три участка) площадей. На обширной территории ТАСП БАО была выделена по преобладанию в россыпях алмазов октаэдрического габитуса
(Больше-Питский, Северо-Енисейский и Нижне-Вельминский алмазоносные районы). В дальнейшем площадь с преобладанием октаэдрических кристаллов была расширена на юго-восток, в направлении простирания Ковино-Кординской и Тарыдакской зон глубинных разломов. Заметное различие алмазов из современных и каменноугольных отложений в бассейне р. Тычана свидетельствует о множественности коренных источников в данном регионе. Алмазы крупнее, чем индивиды большинства современных россыпей юго-запада СП, отмечены в каменноугольных отложениях Тарыдакской и Шушукской площадей. Среди них преобладают кристаллы класса $-2+1$ мм (около 75 \%), при высоком (> 25 \%) количестве алмазов размером $-4+2$ мм и при единичных находках мелких индивидов класса $-1+0,5$ мм. О крупности кристаллов свидетельствует распределение их по массе: на долю камней массой до 10 мг приходится лишь 25 \%. Преобладают (фото) ламинарные кристаллы ряда октаэдр - ромбододекаэдр (преимущественно октаэдры), при заметном (> 25 \%) содержании округлых, в основном с шагренью и полосами пластической деформации. Для сравнения отметим, что в россыпях системы рек Ирелях, Малая Ботуобия и Вилюй (Центрально-Сибирская алмазоносная субпровинция - ЦСАСП), на расстоянии около 300 км от трубки Мир, содержание округлых алмазов уральского типа превышает 20 \%, что сопоставимо с данными для Тычанской площади. Содержание двойников и сростков среди алмазов из Тычанского каменноугольного коллектора низкое (15 \%), причём преобладают шпинелевые двойники. Количество алмазов со скульптурами травления превышает 50 \%, причём преобладает (> 40 \%) леденцовая скульптура. Большинство кристаллов представлено (рис. 1) бесцветными высокопрозрачными алмазами, слабоокрашенных индивидов лишь 35 \%. Около 20 \% составляют кристаллы с зелёными пятнами пигментации. В ультрафиолетовых лучах преобладают индивиды с розово-сиреневым (> 50 \%) и сине-голубым (35\%) свечением. Содержание алмазов с твёрдыми включениями превышает 40 \%. Преобладают эпигенетические включения графита, часто в ассоциации с сульфидами, кристаллов с сингенетическими включениями 6 \%. Большинство включений представлено минералами из ультраосновной ассоциации, но доля включений эклогитовой ассоциации (омфацит + оранжевый гранат) весьма весома (40 \%). Степень сохранности (целостность) алмазов невысокая. В примерно равных количествах присутствуют (рис. 2) целые, повреждённые кристаллы и их обломки. При сравнительно невысокой целостности превалируют алмазы без трещин (около 65 \%). Преобладают индивиды с аллювиальными сколами, а для половины всех кристаллов характерен только механический износ выкрашивания. Для сравнения отметим, что содержание алмазов с таким механическим износом в Малоботуобинском алмазоносном районе (МБАР), на небольшом удалении от трубки Мир, превышает $20 \%$. 


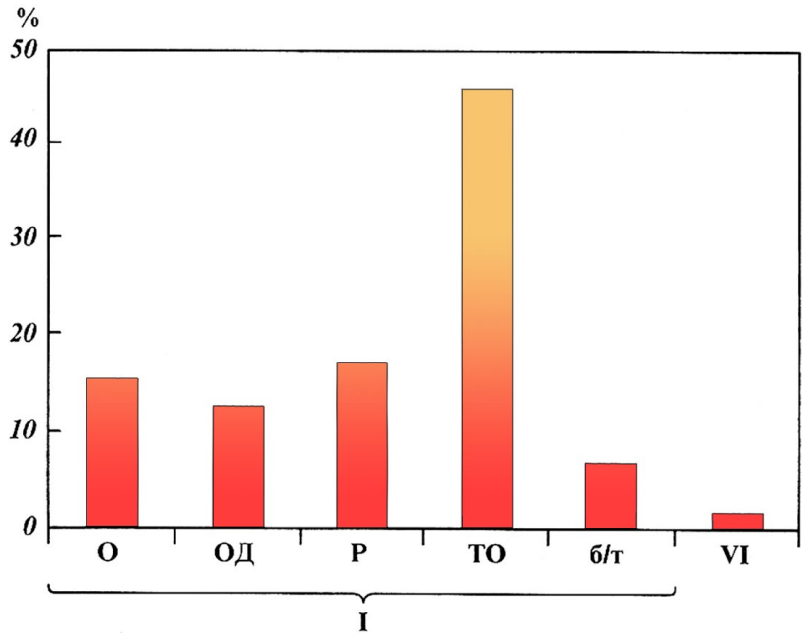

Рис. 1. Типоморфные особенности алмазов бассейна р. Нижняя Тунгуска

I, VI - разновидности алмазов по работам Ю. Л. Орловой $(\mathrm{O}$ - октаэдры, ОД - переходные формы, Р - ламинарные ромбододекаэдры, ТО - сумма типично округлых алмазов, б/т - осколки)

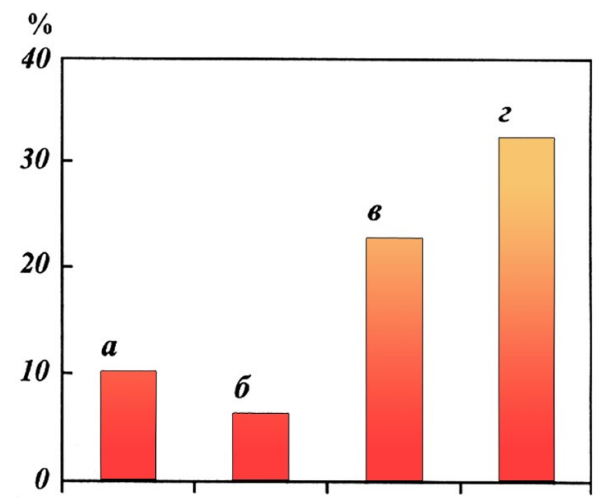

Рис. 2. Некоторые типоморфные особенности алмазов бассейна р. Нижняя Тунгуска

a - двойники и сростки, б - двойники, в - окрашенные алмазы, г- алмазы с твердыми включениями

В каменноугольных отложениях Тычанской площади $[9,15-20]$ преобладают индивиды из кимберлитового первоисточника мирнинского типа (> 50 \%), представленные кристаллами октаэдрического и переходного от него к ромбододекаэдрическому габитусов. Кроме того, присутствуют ромбододекаэдры далдыно-алакитского типа с занозистой штриховкой, додекаэдроиды уральского типа, близкие к ингашинским, а также своеобразные равномерно окрашенные в желтый цвет октаэдроиды II разновидности, аналогичные этой группе алмазов Дьюкунахского района ЦСАСП. Следовательно, по комплексу типоморфных признаков и спектру кристаллов отдельных морфогенетических групп (разновидности, габитус и морфологические типы) алмазы из каменноугольного коллектора Тычанской площади и Байкитской области ТАСП не имеют аналогов среди таковых известных кимберлитовых тел и россыпей Сибирской алмазоносной провинции, что позволяет предполагать их собственные продуктивные коренные источники среднепалеозойского возраста [21-26]. Для них характерна множественность первоисточников (порядка 3-4), которыми могут быть несколько кимберлитовых трубок или, возможно, кимберлитовых полей двух эпох магматизма (среднепалеозойской и докембрийской). Выделяются группы алмазов (не исключена воз- можность смешивания индивидов из нескольких кимберлитовых полей) с преобладанием кристаллов октаэдрического габитуса (> 50 \%), являющихся типоморфным признаком богатых кимберлитовых трубок мирнинского типа, и подчинённой ролью других алмазов, часть из которых встречается только в этом регионе. Материалы комплексного исследования алмазов Южно-Тунгусской области менее информативны. К настоящему времени мы располагаем результатами исследований из Присаянской области (Чуно-Бирюсинский и Ковинский алмазоносные районы), а также 48 кристаллов из Тунгусской площади (Верхне-Катангский, Таймура-Чуньский и Нижне-Тунгусский алмазоносные районы). Алмазы Южно-Тунгусской области [14, 15, 17-20] характеризуются сравнительно небольшим размером (5-10 мг, в среднем 9,4 мг). Преобладают кристаллы класса $-2+1$ мм, при сравнительно небольших, примерно равных количествах классов $-4+2$ мм и -1+0,5 мм (5-10 \%) и единичных находках более крупных индивидов класса $-8+4$ мм. Преобладают типичные округлые алмазы уральского типа (> 50 \%), при заметном содержании поликристаллических образований типа баллас (до 10 \%). На долю кристаллов октаэдрического и переходного от октаэдрического к ромбододекаэдрическому габитусов приходится лишь $25 \%$. Содержание двойников и сростков не более $15 \%$. Много кристаллов с леденцовой скульптурой (до 50 \%), при высоком содержании индивидов с кавернами, матировкой и коррозией (до 20 \%). Подавляющее большинство алмазов обладает высокой степенью прозрачности, а доля окрашенных камней не превышает $35 \%$. Более 20 \% индивидов имеют зеленые и бурые пятна пигментации радиационного происхождения, половину из которых составляют бурые, что на 2-3 порядка выше значений для алмазов из россыпей других районов СП. Практически все изученные кристаллы с бурыми пятнами пигментации представлены округлыми алмазами уральского типа. Несколько реже зеленые пятна пигментации встречаются на додекаэдроидах с шагренью и полосами пластической деформации. Содержание алмазов с признаками ожелезнения составляет $20 \%$, что в 2-3 раза ниже, чем в мезозойских и кайнозойских россыпях северо-востока СП и на два порядка выше, чем в верхнепалеозойских коллекторах МБАР (ботуобинская свита), Приленского (нучча-юрэгинская свита) и Тычанского (тычанская свита) районов. Среди алмазов Южно-Тунгусской области (бассейн р. Нижняя Тунгуска) преобладают кристаллы с сине-голубой фотолюминесценцией, при близких содержаниях индивидов с зеленым (20\%) и розово-сиреневым (17\%) свечением, в чем они напоминают алмазы из нижнекаменноугольных и современных отложений Кютюнгдинской области и ее юго-западного и северо-восточного обрамления. Содержание твердых включений в алмазах около $25 \%$, в том числе сингенетических 6 \%, причем среди последних высокая (20 \%) доля включений эклогитовой ассоциации (оранжевый гранат). Нечто подобное отмечено для алмазов из россыпей северо-востока СП. По степени сохранности (целостности) преобладают (более половины) целые и в незначительной степени поврежденные индивиды, при примерно равных соотношениях (до 20 \%) обломанных кристаллов и обломков. Вместе с тем, более $75 \%$ всех алмазов не имеют трещин, при значительном (>17\%) содержании кристаллов с механическим износом выкрашивания и 4 \% индивидов с серповидными трещинами и ромбическим узором, причем последняя цифра максимальна для россыпей СП. Отсутствуют алмазы с механиче- 
ским износом истирания, который характерен для россыпей северо-востока СП. Приведенные данные свидетельствуют о неоднократных перемыве и переотложении алмазов, обусловивших естественную сортировку и значительную удаленность от первоисточников.

Для алмазов Присаянья (Чуно-Бирюсинский район) характерна повышенная крупность, при высокой средней массе кристаллов $(39,0$ мг), что близко к средней массе из россыпей Урала, имеющих сложную экзогенную историю [9]. Характерной особенностью изученных кристаллов является резкое (97,9 \%) преобладание бесцветных, реже эпигенетически окрашенных в дымчато-коричневые (из-за пластической деформации), а также в зеленые цвета морской волны и желто-бурые (из-за пигментации радиационного происхождения) алмазов I разновидности различной морфологии. Встречены единичные равномерно окрашенные в янтарно-желтый цвет кубы II разновидности, бесцветные полубалласы VI разновидности и серо-стальные карбонадо бразильского типа X разновидности [12-14]. По своим кристалломорфологическим особенностям среди кристаллов I разновидности преобладают (48,9 \%) типичные округлые алмазы уральского (бразильского) типа в основном додекаэдроиды, реже (4,8 \%) октаэдроиды. Следует отметить довольно высокое $(22,1$ \%) содержание кристаллов октаэдрического габитуса, в основном со сноповидной штриховкой (7,6 \%) и полицентрически растущими гранями (7,6 \%), а также плоскогранных острореберных октаэдров (3,4 \%). При сравнительно невысоком содержании кристаллов переходной формы (7,6 \%) и ламинарных ромбододекаэдров $(9,6$ \% ), обращает на себя внимание преобладание гладкогранных скрытослоистых округлых алмазов (в сумме 31,0 \%) над додекаэдроидами с шагренью и полосами пластической деформации (17,9 \%). Для алмазов характерно низкое $(12,1$ \%) содержание двойников и высокое $(70,4$ \%) содержание кристаллов с признаками природного травления, представленных, преимущественно, леденцовой скульптурой в виде сглаживания (оплавления) вершин, рёбер и гранных швов кристаллов. Алмазам присуща высокая степень прозрачности и значительное $(42,1$ \%) содержание окрашенных камней, в основном за счёт приповерхностной бледно-зелёной окраски цвета морской волны радиационного происхождения $(16,6 \%)$, которое снимается при их огранке в бриллианты. Общее содержание индивидов с признаками слабого ожелезнения является очень низким (5,5 \%). Особенностью изученных алмазов является максимальное количество пигментированных камней с зелеными и особенно бурыми пятнами пигментации, что является типоморфным признаком кристаллов из терригенных алмазоносных формаций мира докембрийского возраста. Их общее содержание составляет более $1 / 3(34,4 \%)$ от общего количества индивидов, причем среди них (25,5 \%) преобладают зеленые пятна пигментации также позеленение по трещинам $(3,4$ \% ) радиационного происхождения. Содержание алмазов с бурыми пятнами пигментации (4,1%), а также комбинацией буро-зеленых $(1,4$ \%) по степени распространенности занимает первое место на СП, наряду с бассейном р. Нижняя Тунгуска (8,1%), хотя их суммарное содержание, подверженное метаморфогенному отжигу при температуре $550-600{ }^{\circ} \mathrm{C}$, в Присаянье составляет 8,6 \% (пятна бурые, буро-зеленые и желто-бурые, окраска радиационного происхождения), что близко к кристаллам бассейна р. Нижняя Тунгуска. Следует отметить, что суммарное содержание алмазов с окраской цвета морской волны, зелеными пятнами пигментации и позеленения по трещинам составляет 42,1 \% - максимальное на СП [9], что сближает их с терригенными докембрийскими алмазоносными формациями мира [14], бассейном р. Нижняя Тунгуска [8-10], рядом россыпей Урала [10] и Среднего Тимана [15]. Это, на наш взгляд $[15,17,18]$, свидетельствует о существовании в районе Присаянья высокотемпературных интрузивов основного состава (дайки, штоки и т. д.), внедрение которых привело к региональному метаморфизму алмазоносных древних вторичных коллекторов. Для алмазов характерно низкое $(25,6$ \%) содержание кристаллов с твёрдыми включениями, при высоком (7,7 \%) содержании сингенетических включений, среди которых доминируют включения эклогитовой ассоциации. Алмазы характеризуются высокой степенью сохранности (целостностью) и низкой степенью трещиноватости, при значительном $(22,7$ \%) содержании кристаллов с механическим износом, среди которых много камней с ромбическим узором трещин (7,6 \%). Следует отметить, что среди изученных алмазов полностью отсутствует механический износ истирания, преобладающий (10-45 \%) в разновозрастных россыпя северо-востока СП, а среди таковых в Присаянье преобладают целые высокопрозрачные бесцветные кристаллы, высокое качество которых приближается к таковым из россыпей Урала в сопоставимых классах крупности. Это позволяет, по аналогии с Уралом, предположить, что россыпи Присаянья могут оказаться рентабельными для эксплуатации даже при убогих содержаниях алмазов (в пределах 0,03-0,05 кар/м³). Типоморфными особенностями алмазов Присаянья являются: повышенная крупность кристаллов при средней массе 39,0 мг; резкое преобладание типичных округлых алмазов уральского/бразильского типа (додекаэдроиды, реже октаэдроиды), при единичных находках желтых кубов II разновидности, бесцветных балласов VI разновидности и черных карбонадо бразильского типа $\mathrm{X}$ разновидности; низкое содержание двойников и сростков; высокая роль кристаллов с леденцовой скульптурой, реже своеобразными кавернами без штриховки на днище и тригонтриоктаэдроидов растворения; очень высокая степень прозрачности; невысокое содержание алмазов с лилово-коричневой окраской при преобладании кристаллов с эпигенетической поверхностной окраской цвета морской волны, зелеными и бурыми пятнами пигментации радиационного происхождения с их последующим отжигом при $\mathrm{t}>550{ }^{\circ} \mathrm{C}$ во вторичном коллекторе; низкое содержание индивидов с сингенетическими графит-сульфидными включениями и при высоком содержании сингенетических включений, преимущественно, эклогитового парагенезиса; высокая степень сохранности (целостности) и низкая степень трещиноватости, а также высокое содержание кристаллов со своеобразным механическим износом (выкрашивание, фигуры удара и ромбический узор трещин), при полном отсутствии износа истирания; высокое качество алмазного сырья. Не исключено, что такого рода износ объясняется своеобразием плотика, сложенного высокопрочными породами докембрийского возраста (кварциты, гнейсы, кристаллические сланцы и др.). В целом по своим типоморфным особенностям изученные алмазы близки к кристаллам из россыпей бассейна р. Нижняя Тунгуска, что может, на наш взгляд [8-10], свидетельствовать о генеральном направлении сноса с юго-запада (Присаянье) на северо-восток в пределах Иркутского амфитеатра, начиная с протерозоя. Судя по присутствию балласов в россыпях бассейна р. Нижняя Тунгуска, карбонадо в 
бассейне верхнего течения р. Вилюй и балласов тунгусского типа в Средне-Мархинском алмазоносном районе (СМАР), типичных округлых алмазов и тригонтриоктаэдров I разновидности, снос мог достигать зоны сочленения Тунгусской синеклизы и Анабарской антеклизы (междуречье рек Марха и Тюнг). Рядом типоморфных особенностей изученные алмазы близки к россыпям Урала и Среднего Тимана, но, в отличие от них, характеризуются более высоким (не менее чем в 3-5 раз) содержанием ламинарных кристаллов ряда октаэдр-ромбододекаэдр (преимущественно, октаэдров), что свидетельствует о полигенезе их коренных источников (не менее двух полей докембрийской фазы и одного - для фанерозойской фазы магматизма). Аналогичный спектр алмазов с близкими типоморфными особенностями отсутствует как в кимберлитовых телах, так и россыпях центральной и северо-восточной частей СП. По нашим данным, подобного рода кристаллы также характерны для сопредельных с севером Иркутской области территорий Красноярского края (Верхне-Катангский, Нижне-Тунгусский и Таймура-Чуньский алмазоносные районы).

Результаты комплексного минералогического исследования алмазов Саяно-Тунгусской алмазоносной области свидетельствуют о множественности их коренных первоисточников, которых может быть не менее трех [7-10]. К первому относится значительное ( 30 \%) содержание кристаллов октаэдрического, ромбододекаэдрического и переходного от октаэдрического к ромбододекаэдрическому габитусов I разновидности, характерных для богатых кимберлитовых тел I типа первоисточников фанерозойского возраста, что более чем в пять раз выше по сравнению с россыпями Урала и в 12 раз выше по сравнению с россыпями Среднего Тимана. Вместе с тем среди них преобладают (более 50 \%) округлые алмазы уральского (бразильского) типа I разновидности II типа первоисточника, характерного для кимберлитовых тел с убогой алмазоносностью и кимберлитовых жил [9]. В ассоциации с ними встречаются такие типоморфные признаки алмазов формаций докембрийского возраста, как балласы VI разновидности и карбонадо X разновидности, для которых предполагается некимберлитовый генезис $[14,15,20]$. Следует также отметить и присутствие среди алмазов Присаянья желто-оранжевых кубоидов II разновидности, близких [17] по своим типоморфным особенностям к алмазам метаморфического генезиса кумдыкольского типа (первоисточник третьего типа).

Проведенный нами анализ типоморфных особенностей алмазов Байкитской и Южно-Тунгусской областей ТАСП подтверждает их отличие, что предполагает различную роль коренных источников отдельных эпох кимберлитового магматизма в формировании алмазоносных отложений. Наиболее благоприятна для поисков богатых коренных источников алмазов среднепалеозойского возраста территория Байкитской области. Насколько позволяет судить опоискованность Южно-Тунгусской области, наибольшее влияние на формирование россыпей алмазов здесь оказала докембрийская фаза кимберлитового магматизма в Присаянье и других структур южного обрамления СП, откуда алмазы сносились в Иркутский амфитеатр. Возможные коренные источники среднего палеозоя и мезозоя были убогоалмазоносны и не оказали заметного влияния на россыпную алмазоносность региона. Все это соответствует мнению о приуроченности областей распространения округлых алмазов к полям развития докембрийских терригенных формаций $[14,15,20]$. По подобным признакам поискового прогнозирования возможно обнаружение высокоалмазоносных кимберлитовых тел не только в ЦСАСП, но и в Байкитской области ТАСП.

Подводя итоги комплексного исследования алмазов из каменноугольных отложений юго-западной части СП (бассейн р. Нижняя Тунгуска и Присаянье) следует отметить, что в целом они характеризуются сходством типоморфных особенностей, сближающих их с кристаллами некоторых складчатых областей России (Урал и Средний Тиман). Они схожи также с алмазами из известных докембрийских формаций мира $[14,17]$. Общими чертами, сближающими россыпи двух пространственно разобщенных регионов ТАСП, являются: преобладание типичных округлых алмазов уральского (бразильского) типа І разновидности по Ю. Л. Орлову в ассоциации с балласами VI и карбонадо X разновидностей; низкое содержание двойников и сростков; высокое содержание кристаллов с признаками природного травления (леденцовая скульптура оплавления, каверны, дисковая и черепитчатая скульптуры); высокая степень прозрачности; низкая роль кристаллов с лилово-коричневой и относительно высокая - с бледно-зеленой окраской цвета морской волны, а также зелеными пятнами пигментации радиационного происхождения; малое количество эпигенетических графит-сульфидных включений и сравнительно высокое - сингенетических включений; высокая степень сохранности (целостности) и низкая степень трещиноватости; высокая роль кристаллов со своеобразным механическим износом (выкрашивание, фигуры удара и ромбический узор трещин) при отсутствии механического износа (истирания), характерного для россыпей центральной и северо-восточной части СП. На примере территории Тычанского района показана возможность выделения локальных участков, для которых предполагается множественность первоисточников при преобладании кристаллов мирнинской ассоциации. Региональное распространение на этой территории мелких кристаллов октаэдрического габитуса в пределах юго-западного и северо-восточного бортов Тунгусской синеклизы отличает данный регион от севера Иркутской области и Присаянья. Среди алмазов северной части Саяно-Тунгусской области (бассейн р. Нижняя Тунгуска) по комплексу типоморфных признаков свыше половины составляют кристаллы, близкие по своим свойствам к таковым из терригенных алмазоносных формаций докембрийского возраста других регионов мира. Присутствие в изученной выборке минералов довольно большого количества (до 25 \%) кристаллов I разновидности октаэдрического и переходного от октаэдрического к ромбододекаэдрическому габитусов, преобладающих в богатых кимберлитовых диатремах фанерозойского возраста СП, подчеркивает множественность коренных источников алмазов. Группа типичных алмазов уральского (бразильского) типа в пределах изученной части территории ТАСП по комплексу свойств близка к аналогичной группе кристаллов из периферийных частей северо-востока СП и Восточно-Европейской платформы (Архангельская алмазоносная провинция), что позволяет прогнозировать возможность открытия в исследуемом регионе диатрем, характерных для уже известных в краевых участках упомянутых кратонов. Учитывая полученные материалы наших исследований, вероятно поступление значительной части алмазов в бассейн р. Нижняя Тунгуска из складчатых областей Присаянья, источником которых могут быть терригенные алмазоносные формации докембрийского возраста, подвергшиеся в дальнейшем региональному метаморфизму. Исследуемые алмазы позволяют предполагать также 
возможность термального воздействия на алмазы в условиях древних вторичных коллекторов магматических образований траппового магматизма раннетриасового возраста, что привело к переходу зеленых пятен пигментации в бурые. В целом по своим типоморфным особенностям изученные алмазы близки к кристаллам из россыпей р. Нижняя Тунгуска, что может свидетельствовать о генеральном направлении сноса с юго-запада (Присаянье) на северо-восток в пределах Иркутского амфитеатра, начиная с протерозоя. Судя по присутствию балласов в россыпях бассейна р. Нижняя Тунгуска, карбонадо в бассейне верхнего течения р. Вилюй и балласов тунгусского типа в СМАР, типичных округлых алмазов и тригонтриоктаэдров I разновидности, снос таких алмазов мог достигать зоны сочленения Тунгусской синеклизы и Анабарской антеклизы (междуречье Марха - Тюнг). По ряду типоморфных особенностей изученные алмазы близки к кристаллам россыпей Урала и Среднего Тимана, но в отличие от них, характеризуются более высоким (не менее, чем в 3-5 раз) содержанием ламинарных кристаллов ряда октаэдр-ромбододекаэдр, что свидетельствует о полигенезе их коренных источников (не менее двух полей докембрийской фазы и одного - для мезозойской фазы магматизма). Полученные типоморфные особенности алмазов можно использовать для восстановления экзогенной истории минерала на пути от их источников до мест современного нахождения в россыпях, что очень важно для палеографических реконструкций распространения древних продуктивных отложений и выяснения направлений сноса алмазоносного материала. Результаты минералогического районирования территории россыпной алмазоносности по типоморфным особенностям алмазов позволяют локализовать перспективные площади для поиска коренных источников этого минерала, который является значительно более устойчивым в экзогенных условиях по сравнению с другими мантийными образованиями.

\section{ЛИТЕРАТУРА}

1. Афанасьев В. П., Зинчук Н. Н. Основные литодинамические типы ореолов индикаторных минералов кимберлитов и обстановки их формирования//Геология рудных месторождений. - 1999. - Т. 41. № 3. - C. 281-288.

2. Афанасьев В. П., Зинчук Н. Н., Коптиль В. И. Полигенез алмазов в связи с проблемой коренных россыпей северо-востока Сибирской платформы//Доклады Академии наук. - 1998. - Т. 361. № 3. - С. 366-369.

3. Афанасьев В. П., Зинчук Н. Н., Логинова А. М. Особенности распределения россыпных алмазов, связанных с докембрийскими источниками//Записки Российского минералогического общества. - 2009. - Т. 138. - № 2. - С. 1-13.

4. Афанасьев В. П., Зинчук Н. Н., Тычков С. А. Проблема алмазоносности Сибирской платформы//Вестник Воронежского госуниверситета. Геология. - 2002. - № 1. - С. 19-36.

5. Василенко В. Б., Зинчук Н. Н., Кузнеиова Л. Г. Геодинамический контроль размещения кимберлитовых полей центральной и северной частей Якутской кимберлитовой провинции (петрохимический аспект)//Вестник Воронежского госуниверситета. Геология. - 2000. - № 3 (9). - C. 37-55.

6. Зинчук H. Н. Сравнительная характеристика вещественного состава коры выветривания кимберлитовых пород Сибирской и Восточно-Европейской платформы//Геология и геофизика. - 1992. - № 7. - C. 99-109.

7. Зинчук Н. Н., Борис Е. И., Яныгин Ю. Т. Особенности минерагении алмаза в древних осадочных толщах (на примере верхнепалеозойских отложений Сибирской платформы). - М.: Мирнинская городская типография, 2004. - 172 с.

8. Зинчук Н. Н., Зуев В. М., Коптиль В. И., Чёрный С. Д. Стратегия ведения и результаты алмазопоисковых работ//Горный вестник. - 1997. - № 3. - C. 53-57.
9. Зинчук Н. Н., Коптиль В. И., Борис Е. И., Липашова А. Н. Типоморфизм алмазов из россыпей Сибирской платформы как основа поисков алмазных месторождений//Руды и металлы. - 1999. № 3. - С. 18-31.

10. Зинчук Н. Н., Котельников Д. Д., Соколов В. Н. Изменение минерального состава и структурных особенностей кимберлитов Якутии в процессе выветривания//Геология и геофизика. - 1982. № 2. - С. 42-53.

11. Зинчук Н. Н., Мельник Ю. М., Серенко В. П. Апокимберлитовые породы//Геология и геофизика. - 1987. - № 10. - С. 66-72.

12. Зинчук Н. Н., Савко А. Д., Крайнов А. В. Кимберлиты в истории Земли. Труды НИИ геологии ВГУ. Учебное пособие. - Воронеж: ВГУ, 2013. - Вып. 68. - 100 с.

13. Зинчук Н. Н., Специус З. В., Зуенко В. В., Зуев В. М. Кимберлитовая трубка Удачная. Вещественный состав и условия формирования. - Новосибирск: НГУ, 1993. - 147 с.

14. Квасница В. Н., Зинчук Н. Н., Коптиль В. И. Типоморфизм микрокристаллов алмаза. - М.: Недра, 1999. - 224 с.

15. Котельников Д. Д., Домбровская Ж. В., Зинчук Н. Н. Основные закономерности выветривания силикатных пород различного химического и минералогического типа//Литология и полезные ископаемые. - 1995. - № 6. - С. 594-601.

16. Котельников Д. Д., Зинчук Н. Н. Об аномалии общей схемы преобразования разбухающих глинистых минералов при погружении содержащих их отложений в стратисферу//Вестник Воронежского госуниверситета. Серия геология. - 2003. - № 2. - С. 57-68.

17. Котельников Д. Д., Зинчук Н. Н. Особенности глинистых минералов в отложениях различных осадочных формаций//Известия высших учебных заведений. Геология и разведка. - 1997. - № 2. - С. 53-63.

18. Котельников Д. Д., Зинчук Н. Н. Типоморфные особенности и палеогеографическое значение слюдистых минералов//Известия высших учебных заведений. Геология и разведка. - 1996. - № 1. - С. 53-61.

19. Котельников Д. Д., Зинчук Н. Н. Условия накопления и постседиментационного преобразования глинистых минералов в осадочном чехле земной коры//Вестник Воронежского университета. Геология. - 2001. - № 12. - С. 45-51.

20. Котельников Д. Д., Зинчук Н. Н. Условия накопления и постседиментационного преобразования глинистых минералов в отложениях терригенной формации//Бюллетень Московского общества испытателей природы. Отдел геологический. - 2001. - Т. 76. - № 1. - C. 45-53.

21. Мацюк С. С., Зинчук Н. Н. Оптическая спектроскопия минералов верхней мантии. - М.: Недра, 2001. - 428 с.

22. Харькив А. Д., Зуенко В. В., Зинчук Н. Н., Крючков А. И., Уханов А. В., Богатых М. М. Петрохимия кимберлитов. - М: Недра, 1991. $-304 \mathrm{c}$

23. Хитров В. Г., Зинчук Н. Н., Котельников Д. Д. Применение кластер-анализа для выяснения закономерностей выветривания пород различного состава//Доклады АН СССР. - 1987. - Т. 296. - № 5. - C. $1228-1233$.

24. Vasilenko V. B., Kuznetsova L. G., Volkova N. I., Zinchuk N. N., Krasavchikov V. O. Diamond potential estimation based on Kimberlite major element chemistry//Jornal of Geochecal Exploration. - 2002. Vol. 76. - № 2. - P. 93-112.

25. Grachanov S. A., Zinchuk N. N., Sobolev N. V. The age of Predictable primary diamond sources in the Northeastern Sibirian platform//Doklady Eart Sciences. - 2015. - Vol. 465. - № 2. - P. 1297-1301.

26. Serov I. V., Garanin V. K., Zinchuk N. N., Rotman A. Ya. Mantle Sources of the kimberlite Vorcanism of the Sibirian Platform//Petrology. - 2001. - Vol. 9. - № 6. - P. 576-588.

\section{REFERENCES}

1. Afanasiev V. P., Zinchuk N. N. Main types of litodinamic tipe of kimberlite indication minerals and the conditions of their formation// Geologiya rudnyh mestorozhdenij. - 1999. - Vol. 41. - № 3. - P. 281-288. (In Russian).

2. Afanasiev V. P., Zinchuk N. N., Koptil V. I. Poligines of diamonds in connection with the problem of primary placers of the north-cast of the Siberian platform//Doklady Akademii nauk. - 1998. - Vol. 361. - № 3. - P. 366-369. (In Russian).

3. Afanasiev V. P., Zinchuk N. N., Loginova A. N. Distribution features of placer diamonds associatet with the Precambrian source// Zapiski Rossijskogo mineralogicheskogo obshhestva. - 2009. - Vol. 138. - № 2. - P. 1-13. (In Russian). 
4. Afanasiev V. P., Zinchuk N. N., Tichkov S. A. The problem of dokembriy diamond content of the Sibirian platform//Vestnik VGU. Geologiya. - 2002. - № 1. - P. 19-36. (In Russian).

5. Vasilenko V. B., Zinchuk N. N., Kuznetsova L. G. Geodynamic control of kimberlite fields' allocation of central and northern part of Yakutian kimberlite province (petrochemical aspect)// Vestnik VGU. Geologiya. - 2000. - № 3 (9). - P. 37-55. (In Russian).

6. Zinchuk N. N. Comparative characteristics of material composition of kimberlite rocks' crusts of weathering of the Siberian and East-European platforms//Geologiya i geofizika. - 1992. - № 7. - P. 99-109. (In Russian).

7. Zinchuk N. N., Boris E. I., Yanigin Yu. T. Peculiarities of diamond mineralogene in ancient sedimentary talits by the example of the upper Paleozoic Sediments the Siberian platform. - Mirnyj: MGT, 2004. - 172 p. (In Russian).

8. Zinchuk N. N., Zuev V. M., Koptil V. I., Cherny S. D. Diamond management strategy and results//Gornyj vestnic. - 1997.- № 3.-P.53-57. (In Russian).

9. Zinchuk N. N., Koptil V. I., Boris E. I., Lipashova A. N. Typomorphism of diamonds from placers of the Siberian platform as the basis for prospecting of diamond deposits//Rudy i metally. - 1999. - № 3. P. 18-30. (In Russian).

10. Zinchuk N. N., Kotelnikov D. D., Sokolov V. N. Changes in the mineral composition and structural features of kimberlites of Yakutia during weathering//Geologiya i geofizika. - 1982. - № 2. - P. 42-53. (In Russian).

11. Zinchuk N. N., Melnik Yu. M., Serenko V. P. Apokimberlite rocks// Geologiya i geofizika. - 1987. - № 10. - P. 66-72. (In Russian).

12. Zinchuk N. N., Savko A. D., Krainov A. V. Kimberlites in the Earth history. Proceedings of VSU geological SRI. Tutorials. - Voronezh: VGU, 2013. - Iss. 68. - 100 p. (In Russian).

13. Zinchuk N. N., Spetsius Z.V., Zuenko V. V., Zuev V. M. Kimberlite pipe Udachnaya (material composition and conditions of formation). Novosibirsk: NGU, 1993. - 147 p. (In Russian).

14. Kvasnitsa V. N., Zinchuk N. N., Koptil V. I. Typomorphism of diamond microcrystals. - Moskva: Nedra, 1999. - 224 p. (In Russian).

15. Kotelnikov D. D., Dombrovsraya Zh. V., Zinchuk N. N. Basic laws of weathering of silicate rocks of various chemical and mineralogical types// Litologiya i poleznye iskopaemye. - 1995 - № 6. - P. 594-601. (In Russian).

16. Kotelnikov D. D., Zinchuk N. N. Anomalies of the generals of transformation of swellable clay minerals wher the sediments containing them are immersed in the stratosphere//Vestnik VGU. Geologiya. - 2003. - № 2. - P. 57-68. (In Russian).

17. Kotelnikov D. D., Zinchuk N. N. Features of Clay minerals in sediments of various sedimentary farms//Izvestiya VUZov. Geologiya razvedka. - 1997. - № 2. - P. 53-63. (In Russian).

18. Kotelnikov D. D., Zinchuk N. N. Typomorphic phic features and paleogeographic Significance of mica minerals//Izvestiya VUZov. Geologiya i razvedka. - 1996. - № 1. - P. 53-61. (In Russian).

19. Kotelnikov D. D., Zinchuk N. N. Geological interpretation of the rezultationts of the Sedimentary cover on the larth's crust//Vestnik VGU. Geologiya. - 2001. - № 2. - P. 45-51. (In Russian).

20. Kotelnikov D. D., Zinchuk N. N. Conditions for the accumulation and post-sedimentations transformation of clay minerals in sediments of terrigens formatation//Bulleten MOIP. Otdel geologicheskij. - 2001. Vol. 76. - № 1. - P. 45-53. (In Russian).

21. Macyuk S. S., Zinchuk N. N. Optical Spectroscopy of minerals of the upper mantle. - Moskva: Nedra, 2001. - 428 p. (In Russian).

22. Harkiv A. D., Zuenko V. V., Zinchuk N. N., Krutchkov A. I., Uchanov A. V., Bogatich M. M. Petrochimiya of kimberlite. - Moskva: Nedra, 1991. - 304 p. (In Russian).

23. Hitrov V. G., Zinchuk N. N., Kotelnikov D. D. Application of cluster-analysis for clearing out regularities of various composition rocks' weathering//Doklady AN SSSR. - 1987. - Vol. 296. - № 5. - P. 1228-1233. (In Russian).

24. Vasilenko V. B., Kuznetsova L. G., Volkova N. I., Zinchuk N. N., Krasavchikov V. O. Diamond potential estimation based on Kimberlite major element chemistry//Jornal of Geochecal Exploration. - 2002. Vol. 76. - № 2. - P. 93-112.

25. Grachanov S. A., Zinchuk N. N., Sobolev N. V. The age of Predictable primary diamond sources in the Northeastern Sibirian platform// Doklady Eart Sciences. - 2015. - Vol. 465. - № 2. - P. 1297-1301.

26. Serov I. V., Garanin V. K., Zinchuk N. N., Rotman A. Ya. Mantle Sources of the kimberlite Vorcanism of the Sibirian Platform//Petrology. - 2001. - Vol. 9. - № 6. - P. 576-588.

Рукопи с о тримано 21.09.2019.

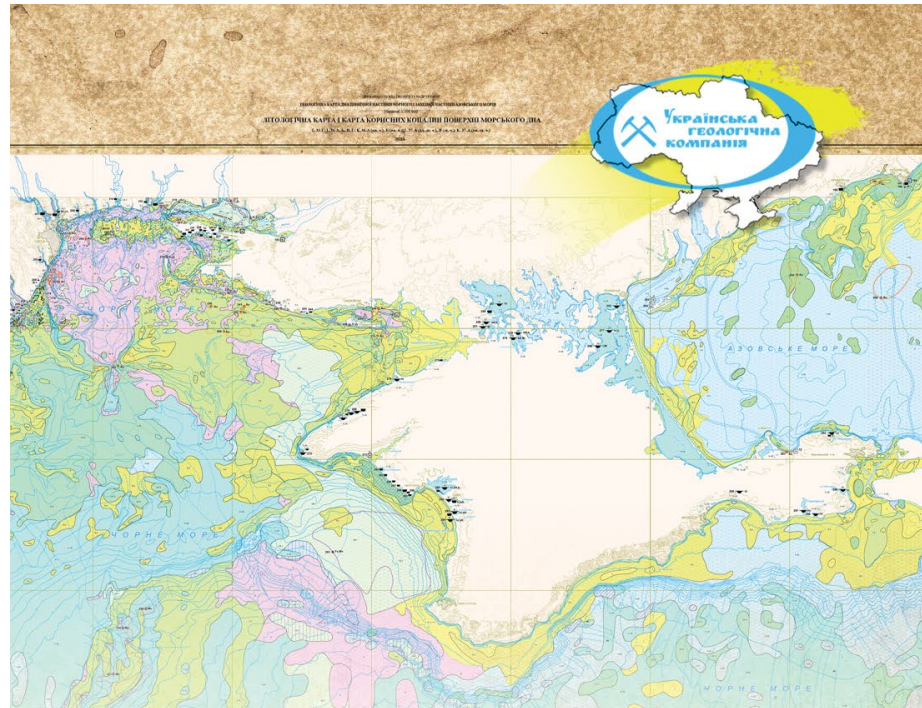

у 2021 р. видавництво

ДП "Українська геологічна компанія" готує до видання комплект карт

\section{"ГЕОЛОГІЧНА КАРТА ДНА ПІВНІЧНОÏ ЧАСТИНИ ЧОРНОГО I ЗАХІДНОЇ ЧАСТИНИ АЗОВСЬКОГО MOPIB"}

Аркуші L-35-Г; L-36-A, -Б, -B, -Г; K-36-A (пн. Ч.), -Б (пн. ч.); L-37-A (пд.-3X. ч.), -B (3X. ч.); K-37-A (пн.-3X. ч.).

\section{До комплекту карт увійшли:}

“Літологічна карта і карта корисних копалин поверхні морського дна”, “Геологічна карта і карта корисних копалин четвертинних відкладів" i “Геоморфологічна карта" масштабу 1:500 000; “Геологічна карта і карта корисних копалин дочетвертинних утворень" i "Схема неотектонічних та сучасних рухів" масштабу 1:1000 000.

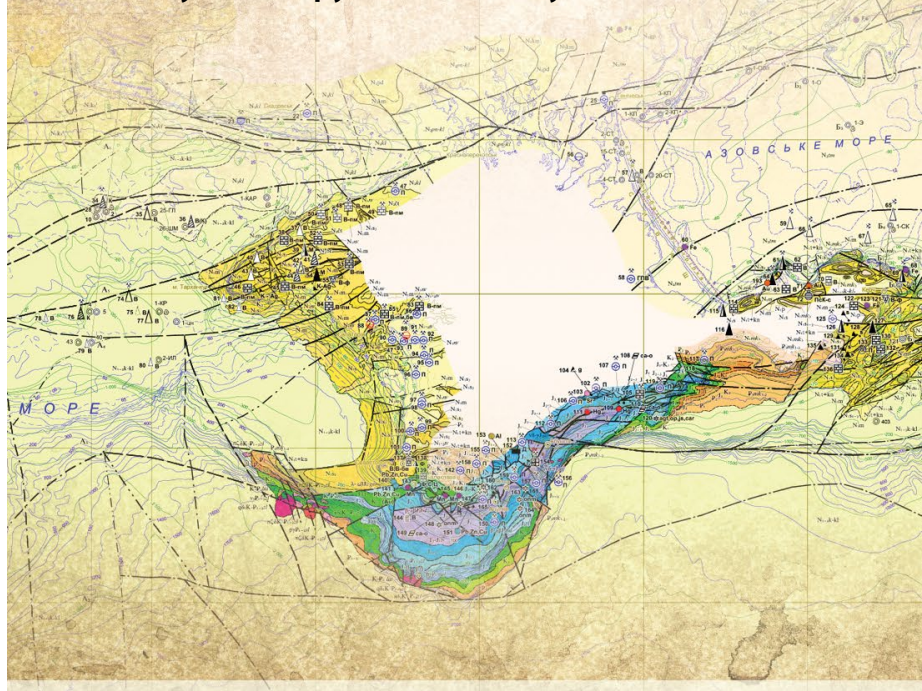

